\title{
Improving weed control in sustainable agro-ecosystems: Role of cultivar and termination timing of rye cover crop
}

\author{
Roberta Boselli, ${ }^{1}$ Nico Anders, ${ }^{2}$ Andrea Fiorini, ${ }^{1}$ Cristina Ganimede, ${ }^{1}$ Nadia Faccini, ${ }^{3}$ \\ Adriano Marocco, ${ }^{1}$ Margot Schulz, ${ }^{4}$ Vincenzo Tabaglio ${ }^{1}$ \\ ${ }^{1}$ Department of Sustainable Crop Production, Università Cattolica del Sacro Cuore, Piacenza, Italy; \\ ${ }^{2}$ AVT-Enzyme Process Technology, RWTH Aachen University, Aachen, Germany; ${ }^{3}$ CREA Research Centre \\ for Genomics and Bioinformatics, Fiorenzuola d'Arda (PC), Italy; ${ }^{4}$ IMBIO Institute, University of Bonn, \\ Bonn, Germany
}

\author{
Highlights \\ - One month after rye termination, the weed biomass under mulching is reduced by 4 times, compared with the control. \\ When rye is terminated early, the allelochemical content in rye tissues reduces the weed biomass production. \\ When rye is terminated late, the weed biomass production is reduced by the amount of rye biomass. \\ - Lambsquarters, redroot pigweed and purslane growth is inhibited by rye mulching, while velvetleaf is not affected.
}

\footnotetext{
Correspondence: Andrea Fiorini, Department of Sustainable Crop Production, Università Cattolica del Sacro Cuore, Via Emilia Parmense 84, 29122 Piacenza, Italy.

E-mail: andrea.fiorini@unicatt.it
}

Key words: Cover crops; rye; allelopathy; weed control; mulch; benzoxazinoids; isovitexin.

Acknowledgements: we would like to thank colleagues, technicians, and students from the Agronomy group of the Department of Sustainable Crop production (Università Cattolica del Sacro Cuore of Piacenza), for their assistance throughout the experiment.

Funding: this study was supported by Romeo and Enrica Invernizzi Foundation (Italy), project 'C3S INVERNIZZI EXPO 2015'.

Contributions: VT, CG, MS, AM, conceptualization; VT, CG, NF, MS, methodology; RB, CG, NA, investigation and original draft writing; $\mathrm{RB}, \mathrm{AF}$, formal analysis; $\mathrm{VT}, \mathrm{AF}, \mathrm{NF}, \mathrm{MS}$, manuscript review and editing; VT, AM, funding acquisition; NF, VT, AM, resources; VT, MS, supervision.

Conflict of interest: the authors declare no potential conflict of interest.

Received for publication: 15 January 2021.

Revision received: 15 April 2021.

Accepted for publication: 26 April 2021.

CCopyright: the Author(s), 2021

Licensee PAGEPress, Italy

Italian Journal of Agronomy 2021; $16: 1807$

doi:10.4081/ija.2021.1807

This article is distributed under the terms of the Creative Commons Attribution Noncommercial License (by-nc 4.0) which permits any noncommercial use, distribution, and reproduction in any medium, provided the original author(s) and source are credited.

\begin{abstract}
Alternative strategies to control weeds are required at the field level to reduce herbicides and derived pollution. As cover crop, rye (Secale cereale L.) is adopted mainly because of its allelopathic weed control, which takes place through a strong inhibition of germination and seedling growth in several types of grass and broad-leaved weeds. The present study consisted of: i) a field trial, focused on the evaluation of biomass production and allelochemical concentration in the biomass, and in situ weed control at 30 days after termination (with two termination timings: T1 - heading phase and T2 - 10 days later) of 8 rye varieties; ii) a pot experiment, focused on the inhibition effect of mulches derived by those 8 rye varieties on four summer weeds: velvetleaf (Abutilon theophrasti Med.), lambsquarters (Chenopodium album L.), redroot pigweed (Amaranthus retroflexus L.), and common purslane (Portulaca oleracea L). Results showed that biomass production was the highest with Protector, closely followed by Primizia, Sito 70, Hellvus, Forestal, and Hymonta. In any case, rye mulching always reduced the weed biomass, especially with Fasto and Forestal. The allelochemical concentration in the biomass was the highest with Fasto and Forestal and decreased on average from T1 to $\mathrm{T} 2$ ( $-38 \%$ for total benzoxazinoids and $-57 \%$ for isovitexin). Conversely, the rye biomass production increased (on average + $77 \%$ ), passing from $\mathrm{T} 1$ to $\mathrm{T} 2$. We also found that the reduction of weed biomass, compared with the control, is highly correlated with the allelochemical content in rye biomass in the case of T1 termination, while with the biomass production in the case of $\mathrm{T} 2$. In pots, a strong inhibitory effect on seedling growth due to rye mulching was observed for $C$. album $(-76 \%)$, A. retroflexus $(-56 \%)$, and $P$. olearcea (-84\%), while not for A. theophrasti.

We concluded that, regardless of the variety, adopting rye as a cover crop may be considered as a suitable practice to reduce weed pressure at the field level. Among all the varieties tested, Forestal and Protector showed the most significant weed suppres-
\end{abstract}


sion potential, due to the high amount of allelochemicals production for Forestal and high biomass production for Protector.

\section{Introduction}

Weed control strategies based on the use of herbicides are expensive and may negatively affect the quality of soil, water, and air (Felsot et al., 2011). Moreover, in the last decades, the excessive use of chemical herbicides led to the development of herbicide resistance: 262 species of herbicide-resistant weeds have been detected on 93 crops in 70 countries (Beckie, 2020). Consequently, a growing interest in alternative strategies for weed management has been stimulated worldwide to address crop production's current economic and environmental challenges (Kumar et al., 2020). In addition, the European Commission recently stated ambitious goals for reducing herbicide use $(-50 \%)$ at the field level by 2030 (European Commission, 2020).

The use of cover crops (CCs) has long been indicated as a good solution for limiting weed development in a broad series of agroecosystems, thus reducing herbicide use and cost (Barnes and Putnam, 1983). Furthermore, it was shown that selected CC species (e.g., gramineous plants) might suppress weeds due to their high competitiveness for space, light, water, and nutrient use (Hiltbrunner et al., 2007). Also, CC residues that remain on the soil surface can limit weed germination and development by reducing light transmittance and soil temperature (Wayman et al., 2015). In addition, some CCs produce allelochemical compounds as secondary metabolites [(e.g., benzoxazinoids, flavonoids, alkaloids, etc. (Scavo et al., 2019)], which are released both by living or decaying plant tissues, and exert a firm control on weeds (Liebman and Davis, 2015).

A plant species considered a reference for allelopathic weed control is rye (Secale cereale L.) (Tabaglio et al., 2008). Rye is one of the most commonly used winter cover crops due to high biomass production, soil and climate adaptability, nitrous oxide emission mitigation, and weed suppression potential (Gavazzi et al., 2010; Fiorini et al., 2020). After termination, rye mulch can be left on the soil surface (i.e., in the case of no-till soil management) to ensure a persistent inhibitory effect on weed germination and development (Mirsky et al., 2013; Tabaglio et al., 2013). Beyond the suppressing effect of rye mulch on weeds, which highly depends on the thickness of the mulch layer (Teasdale and Mohler, 2000), rye residue maintained on the soil surface was reported to release the benzoxazinoids 2,4-dihydroxy-1,4 (2H)-benzoxazin-3-one (DIBOA) and benzoxazolin-2(3H)-one (BOA) (Schulz et al., 2013). Those allelochemical compounds strongly inhibit the germination and seedling growth of several types of grass and broad-leaved spontaneous plants (Macías et al., 2019). Under field conditions, the amount of benzoxazinoids (BX) released by rye is estimated to range between 0.5 and $5 \mathrm{~kg} \mathrm{ha}^{-}$ 1 , depending on the variety and date of the phenological phase of termination (Reberg-Horton et al., 2005). Rice et al. (2005) reported that BX concentration consistently decreases in rye tissues from tillering to flowering. However, previous studies did not consider the benzoxazinoid component bound to the cell wall: this component is probably not available immediately after rye termination, but it can be released gradually afterward, affecting the long-term allelochemical potential.

Besides benzoxazinoids, also flavonoids have a high allelopathic potential: isovitexin was isolated in flavonoid fraction of oat (Avena sativa L.) (de Bertoldi et al., 2009), which demonstrated good control of weeds.
A clear assessment of relationships between rye varieties and allelochemical concentration under field conditions is missing in our soil-climate conditions. Only a few studies previously compared the effect of termination time on allelochemical concentration in different rye varieties, evaluating the effect on weed development under both field and greenhouse conditions. In addition, previous studies did not assess the concentration of cell wallbound BOA, which may contribute to a long-term allelopathic effect. The present study aims to: i) identify the best rye varieties for benzoxazinoids and isovitexin concentrations and production to improve sustainable weed control; ii) find the combination rye variety $\times$ termination timing that can exert the highest and lasting level of weed suppression. We hypothesized that terminating the cover crop early (at the heading phase) may enhance the allelochemical content and, consequently, the control of weeds.

\section{Materials and methods}

\section{Field experiment}

The field trial was carried out at CREA Institute, located in Fiorenzuola d'Arda, Piacenza, Northern Italy (lat. 44.926383 N; long. $9.890661 \mathrm{E})$, from October 2014 to July 2015.

Soil characteristics $(0-30 \mathrm{~cm}$ soil depth) at the beginning of the experiment are reported in Table 1.

The climate is temperate; mean annual rainfall and temperature are $774 \mathrm{~mm}$ and $12.8^{\circ} \mathrm{C}$, respectively. Climatic data during the experiment were collected from an automated meteorological station situated close to the experimental field (Figure 1).

The experiment compared 8 treatments, corresponding to 8 rye varieties ( 6 cultivars: Dukato, Fasto, Forestal, Primizia, Protector, and Sito 70; 2 hybrids: Hellvus and Hymonta), each one replicated 4 times, for a total of 32 main plots (plot area of $10.2 \mathrm{~m}^{2}$ ). Then, each plot was divided into two sub-plots (sub-plot area of $5.1 \mathrm{~m}^{2}$ ) according to the two selected rye termination timings (i.e., at heading phase [T1] and 10 days after the full heading phase [T2]), thus obtaining a total number of 64 sub-plots. As a result, a split-plot (SP) experimental design was obtained, where the main factor was the rye variety, and the secondary factor was the rye termination timing. On $29^{\text {th }}$ October 2014, rye was sown using an 8-row plotseeder (mod. Wintersteiger), the seeding rate was $110 \mathrm{~kg} \mathrm{ha}^{-1}$. Four more plots (one for each block) without rye were used as a control. In the control plots, the vegetation was let to grow spontaneously.

Table 1. Soil physical and chemical properties $(0-30 \mathrm{~cm}$ depth) at the beginning of the experiment (2014).

\begin{tabular}{lcc} 
Soil property & Unit & Value \\
Sand $(2-0.05 \mathrm{~mm})$ & $\mathrm{g} \mathrm{kg}^{-1}$ & 190 \\
Silt $(0.05-0.002 \mathrm{~mm})$ & $\mathrm{g} \mathrm{kg}^{-1}$ & 470 \\
\hline Clay $(<0.002 \mathrm{~mm})$ & $\mathrm{g} \mathrm{kg}^{-1}$ & 340 \\
$\mathrm{pH}\left(\mathrm{H}_{2} \mathrm{O}\right)$ & - & 8.1 \\
\hline $\mathrm{CaCO}_{3}$ (volumetric) & $\%$ & 8.9 \\
Organic matter (Walkley and Black) & $\mathrm{g} \mathrm{kg}^{-1}$ & 22 \\
\hline Total N (Kjeldahl) & $\mathrm{g} \mathrm{kg}^{-1}$ & 1.3 \\
Available P (Olsen) & $\mathrm{mg} \mathrm{kg}^{-1}$ & 14 \\
\hline Exchangeable K (Ba chloride, $\mathrm{pH} \mathrm{8.1)}$ & $\mathrm{mg} \mathrm{kg}^{-1}$ & 190 \\
\hline
\end{tabular}


Fertilization was carried out twice: i) before sowing using a ternary fertilizer (15-15-15) applying $45 \mathrm{~kg} \mathrm{ha}^{-1}$ of $\mathrm{N}, 20 \mathrm{~kg} \mathrm{ha}^{-1}$ of $\mathrm{P}$, and $37 \mathrm{~kg} \mathrm{ha}^{-1}$ of $\mathrm{K}$; ii) at the end of the tillering using ammonium nitrate $(26 \% \mathrm{~N})$ distributing $52 \mathrm{~kg} \mathrm{ha}^{-1}$ of $\mathrm{N}$.

The phenological and yield data were determined in the subplot area according to the following termination timing: (T1) at the heading phase and (T2) 10 days after. The aboveground biomass production was obtained by cutting the whole sub-plots biomass manually at the two termination timings. Prior to each cut, plant height was determined by measuring 20 randomly chosen plants from the ground level for each subplot. After cutting, rye aboveground biomass was weighted in the field. A sub-sample of about $800 \mathrm{~g}$ was collected to be used: i) as rye mulch for the pot trial (only for sub-plots harvested at T1, as described below); and ii) for the allelochemical analyses on a dry matter basis, after being ovendried at $65^{\circ} \mathrm{C}$ to constant weight. The remaining biomass was left onto the soil as mulch for evaluating the effect on weed development directly into the field. Weed density was measured in each sub-plot, placing twice randomly a circle of $0.125 \mathrm{~m}^{2} 30$ days after both rye termination timing. Weeds in each sampling area were collected and oven-dried at $105^{\circ} \mathrm{C}$ for 48 hours for calculating the total dry weight per plot.

\section{Greenhouse pot experiment}

A greenhouse experiment was set up using rye biomass harvested at $\mathrm{T} 1$. The experiment was conducted immediately after rye harvest, and it was designed as a randomized complete block (RCB) with 8 treatments and 6 replicates. The 8 treatments were represented by the 8 rye varieties used in the field trial. The experiment was conducted using plastic pots $(30 \times 9 \times 14 \mathrm{~cm}$, with a surface area of $0.027 \mathrm{~m}^{2}$ ), filled with $2.4 \mathrm{~kg}$ of soil moistened at the field capacity.

In each pot was sown one of the following summer weeds: i) Abutilon theophrasti Med. (velvetleaf); ii) Chenopodium album L. (lambsquarters); iii) Amaranthus retroflexus L. (redroot pigweed); and iv) Portulaca oleracea L. (common purslane). The germination of weed seeds was tested in Petri dishes before starting the experiment. The selected seeds for each pot were: 20 seeds of $A$. theophrasti, 30 seeds of C. album, 30 seeds of $A$. retroflexus, and 30 seeds of $P$. oleracea.

The rye biomass collected in each $\mathrm{T} 1$ sub-plot of the field experiment was shredded into pieces of $2 \mathrm{~cm}$ and put on the top of the corresponding pot. To simulate field conditions, we used fresh biomass: the amount of rye biomass put on each pot was computed, reporting the average fresh biomass production per hectare (33.9 $\mathrm{Mg} \mathrm{ha}^{-1}$ ) to the pot surface, obtaining $91.5 \mathrm{~g}$ of fresh biomass per pot. Therefore, depending on the different varieties and their dry matter content, from 10.3 to 14.8 grams (on a dry matter basis) of rye mulch were placed onto the soil.

In addition, 6 pots without mulch were prepared for control. The soil was then kept at the field capacity using pot plates. The study was carried out for 30 days. During the experimental period, 10 counts of emerged seedlings were carried out every 3 days. Seedlings that emerged were counted at cotyledon appearance and then removed.

\section{Determination of benzoxazinoid and isovitexin concen- tration}

Unbound BX and isovitexin concentrations were determined on sub-samples of rye collected in each sub-plot at both termination timing by extraction of $20 \mathrm{mg}$ of dry material (ground at 0.2 mm by using a Buhler mill mod. MLI 205), which were vortexed for 1 min with $200 \mu \mathrm{L}$ of water prior addition of $400 \mu \mathrm{L} \mathrm{MeOH}$. The mixture was sonicated for 5 minutes and then centrifuged for 3 minutes at 20,000 rpm. The supernatant was immediately transferred into a new cap, stored on ice. $30 \mu \mathrm{L}$ of the supernatant were analysed within the next 2 hours by HPLC-DAD (Shimadzu) using a Nucleodur C18 column (Macherey-Nagel, Düren, Germany). The data obtained were from 3 different extractions of the same mulch sample. For elution, the following gradient was used: 0-5 $\min , 16 \% \mathrm{~B}$ in $\mathrm{A} ; 22 \mathrm{~min}, 30 \% \mathrm{~B}$ in $\mathrm{A} ; 30 \mathrm{~min}, 50 \% \mathrm{~B}$ in $\mathrm{A} ; 32$ $\min , 70 \% \mathrm{~B}$ in $\mathrm{A} ; 35 \mathrm{~min}, 100 \% \mathrm{~B} ; 39 \mathrm{~min}, 100 \% \mathrm{~B}$; $48 \mathrm{~min}, 100 \%$ B, 55 min, 16\% B in A. Solvent A was $\mathrm{H} 2 \mathrm{O} / 0.01 \%$ formic acid and solvent $\mathrm{B}$ : $\mathrm{MeOH}$ were bought from Baker. The runs were analysed with the Shimadzu Software. The amounts of GDIBOA, DIBOA, BOA, and isovitexin were calculated using standard external curves established with GDIBOA, DIBOA, BOA, and isovitexin. Reference substances GDIBOA and DIBOA were from Dieter Sicker (University of Leipzig, Germany), BOA was purchased from SIGMA, and isovitexin was from Phytoplan (Heidelberg, Germany).

For evaluation of cell wall-bound BOA in the dried rye material, $3 \times 1 \mathrm{~g}$ of each sample was hydrolysed. Subsequently, after $\mathrm{MeOH} /$ water extraction to remove unbound benzoxazinoids, the extracted rye material was hydrolysed with sulfuric acid. The twostep sulfuric acid hydrolysis process, firstly described by Sluiter et al. (2008), was performed according to Anders et al. (2015) and Schulz et al. (2016). The extracted rye material and $72 \%$ sulfuric acid were added into a flask in a ratio of 1/16.4 (w/w). The first hydrolysis step was performed in a $12 \mathrm{~L}$ autoclave (Omnilab, Germany) for $1 \mathrm{~h}$ at $121^{\circ} \mathrm{C}$. Hereinafter, the liquid was diluted with water to a final sulfuric acid concentration of $4 \%$. The second hydrolysis process was performed again for $1 \mathrm{~h}$ at $30^{\circ} \mathrm{C}$. Finally, an aliquot of the remaining liquid was filtrated and pipetted into an HPLC vial for analysis.

After the cell wall degrading sulfuric acid hydrolysis process, the supernatant was analysed with an LC-ESI-Q-ToF-MS (Agilent, USA) system (Anders et al., 2017). This system was equipped with a 1260 Infinity high-performance liquid chromatography and a 6530 accurate mass Q-ToF LC/MS. An RP-18 LiChrospher $(250 \times 4$ $\mathrm{mm}, 5 \mu \mathrm{m})$ purchased from CS Chromatography (Germany) was used for chromatography under the following conditions: injection

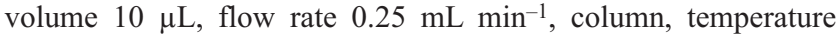
$40^{\circ} \mathrm{C}$, isocratic elution with methanol: acidified water $(40 \% ; 60 \%)$. The MS was run under positive ionization mode. The software used for measurement and data calculation was Masshunter.

Additional HPLC-UV analyses were performed in order to demonstrate the stability of BOA under acidic conditions. The

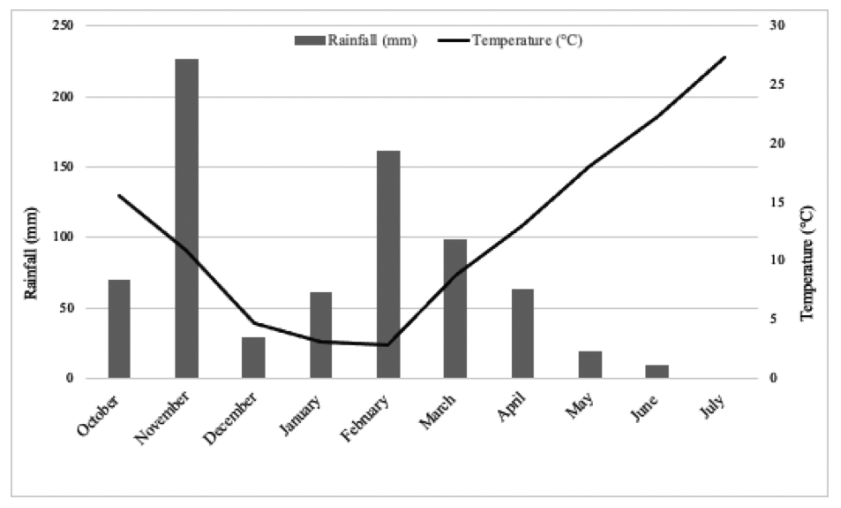

Figure 1. Monthly rainfall (columns) and air temperature (line) during the field experiment (October 2014 - July 2015). 
HPLC-UV device used to measure the degradation process was an Agilent 1260 device (1260 ALS autosampler, 1260 quat pump, 1290 thermostat, and 1260 diode array detector). The above-mentioned RP-18 LiChrospher column was suitable for the separation of BOA, DIBOA, and degradation products. The separation was performed with a flow rate of $0.5 \mathrm{~mL} \mathrm{~min}{ }^{-1}$, injection volume of $10 \mu \mathrm{L}$, and an aqueous methanol eluent (60\%). OpenLab software was used for the visualization of the results (Figure 2).

Acidic solutions of BOA and DIBOA reference standards were prepared with sulfuric acid according to the procedure described above and subsequently injected on an HPLC column. The acidic treatment had no impact on BOA degradation. DIBOA was degraded into BOA. Contrarily to the mild conditions in vivo, the acidic and high-temperature treatment accelerated the degradation of DIBOA; thus, the BOA sum parameter is the sum of BOA and acidically degraded DIBOA. The sum parameter of BOA was calculated based on the LC-ESI-Q-ToF-MS results by using a BOA reference standard.

\section{Statistical analysis}

\section{Field experiment}

Analysis of variance (ANOVA) for a split-plot design was performed using JMP, Version 10 (SAS Institute Inc., Cary, NC, 19892010) software for statistical analysis. The normal distribution of the measured variables was verified using the Shapiro-Wilk test; when necessary, in order to accomplish the assumption of normality, data were log-transformed before analysis. Significant differences among treatment means were further examined using Tukey's multiple range test $(\mathrm{P} \leq 0.05)$.

Multivariate analysis was carried out to investigate the relationship among rye biomass production, allelochemical content (obtained multiplying the allelochemical concentration in different rye varieties for the respective biomass production), and weed biomass, using Pearson's correlation coefficient (r). A P-value of 0.05 was used as a threshold for statistical significance.

\section{Pot experiment}

Analysis of variance (ANOVA) was conducted using JMP, Version 10. All variables were examined for normality with the Shapiro-Wilk test; when the test did not confirm the assumptions of ANOVA, data were log-transformed before analysis. The means of emerged weed seedlings in each of the 8 treatments were compared using Tukey's test $(\mathrm{P} \leq 0.05)$.

\section{Results}

\section{Field experiment: plant height and aboveground bio- mass of rye}

As expressed both on a fresh and dry matter basis, the plant height and the biomass production were significantly affected by rye variety, and the interaction variety $\times$ termination timing $(\mathrm{V} \times$ T) was also significant (Table 2). Within rye cultivars, Primizia, Sito 70, and Protector had the highest values of plant height at T1, while Protector, Primizia, and Forestal showed the highest plant height at T2. On the other hand, Dukato $(71 \mathrm{~cm}$ at T1 and $104 \mathrm{~cm}$ at $\mathrm{T} 2 \mathrm{~cm}$ ) had significantly lower plant height than other cultivars. As regards the hybrids, the height of Hymonta and Hellvus plants, instead, was intermediate between the highest and the lowest cultivars (Table 3 ).

From the first (T1) to the second (T2) termination timing, an overall significant increase in plant height was detected $(+35 \%)$ (Table 3). Sito 70 showed a slight increase in plant height $(+5 \%)$, while for Hymonta and Forestal, the plant height grown considerably ( +65 and $+73 \%$, respectively) from $\mathrm{T} 1$ to $\mathrm{T} 2$.

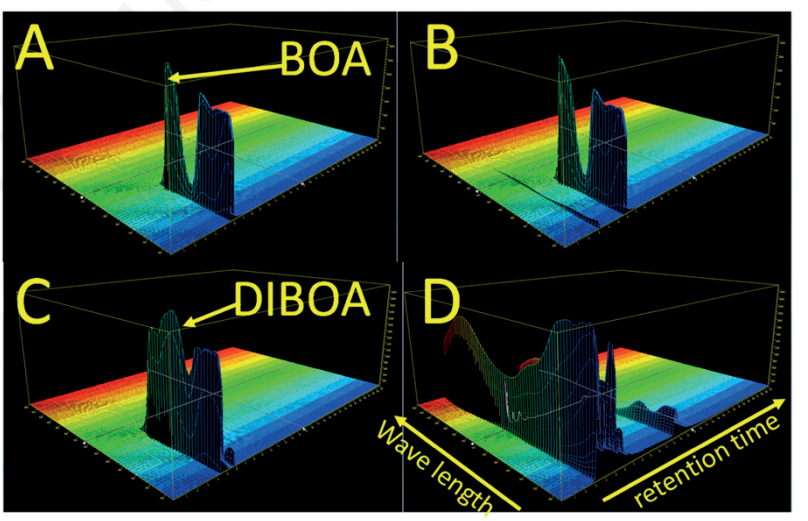

Figure 2. HPLC-DAD chromatogram of benzoxazolin- $2(3 \mathrm{H})$-one (BOA) (A: $5.867 \mathrm{~min}$ ) and benzoxazinoids 2,4-dihydroxy-1,4 (2H)-benzoxazin-3-one (DIBOA) (C: $4.513 \mathrm{~min}$ ). Both samples were hydrolysed using sulfuric acid in order to degrade both standards. The subsequent analysis of the liquid BOA and DIBOA solution showed no degradation of BOA (see B). However, DIBOA was degraded as shown in the DAD chromatogram shown in $D$.

Table 2. Analysis of variance (ANOVA) of the effects of rye variety $(\mathrm{V})$, termination timing $(\mathrm{T})$, and their interaction $(\mathrm{V} \times \mathrm{T})$ on plant height, biomass production, and allelochemical concentration in the biomass of rye, and weed biomass in the field trial.

\begin{tabular}{|c|c|c|c|c|}
\hline Trial & Parameter & Variety (V) & $\begin{array}{c}\text { Source of variation } \\
\text { Termination (T) } \\
\text { P-value }\end{array}$ & $\mathrm{V} \times \mathrm{T}$ \\
\hline Field trial & $\begin{array}{l}\text { Plant height } \\
\text { Fresh biomass } \\
\text { Dry biomass } \\
\text { Weed biomass } \\
\text { Total BX concentration } \\
\text { BOA from cell wal hydrol. conc. } \\
\text { Isovitexin concentration }\end{array}$ & $\begin{array}{l}<0.0001 \\
0.0040 \\
<0.0001 \\
<0.0001 \\
<0.0001 \\
<0.0001 \\
<0.0001\end{array}$ & $\begin{array}{c}<0.0001 \\
<0.0001 \\
<0.0001 \\
0.4502 \\
<0.0001 \\
<0.0001 \\
<0.0001\end{array}$ & $\begin{array}{l}<0.0001 \\
0.0063 \\
0.0087 \\
0.1305 \\
0.0399 \\
0.2730 \\
0.3720 \\
\end{array}$ \\
\hline
\end{tabular}


The biomass production on a fresh matter basis was the lowest for Dukato $(-29 \%$ compared to average production of the other varieties), while no significant difference occurred among the other 7 varieties (Table 3 ). On the other hand, the overall fresh biomass yield increased by $25 \%$, passing from the early (T1) to the late (T2) termination timing (Table 3). As for plant height, the interaction $\mathrm{V} \times \mathrm{T}$ was significant. Indeed, the increase in fresh biomass production from T1 to T2 was less than $10 \%$ for Primizia, Protector, and Sito 70 , whereas it exceeded $80 \%$ for Dukato.

Considering the dry biomass yield, Protector had the highest dry biomass production, significantly higher than Fasto and Dukato; the last one yielded 53\% less than Protector, confirming the less productive variety (Table 3 ).

Passing from the heading stage (T1) to the beginning of the flowering stage (T2), the average dry biomass production significantly increased by $77 \%$ (Table 3 ); again, the interaction $\mathrm{V} \times \mathrm{T}$ was significant. Indeed, the dry biomass production increased only by
$34 \%$ for Primizia from T1 to T2, whereas it was more than doubled at T2 than at T1 for Hellvus, Hymonta, and Forestal.

\section{Field experiment: concentration of allelochemicals in rye biomass}

The allelochemical concentration in dry biomass varied considerably among rye cultivars, and a decrease in the overall allelochemical concentration was observed from T1 to T2 (Figure 3). However, the interaction $\mathrm{V} \times \mathrm{T}$ was significant only for isovitexin (Table 2).

On average, the total BX concentration in rye biomass (Figure $3 \mathrm{~A})$ terminated at the heading phase (T1) was $61 \%$ higher than that recorded 10 days later (T2) (848 vs $525 \mu \mathrm{g} \mathrm{g}^{-1}$ of dry matter). Fasto, Forestal, Primizia, and Hymonta had the highest BX concentration at $\mathrm{T} 1\left(1034,1009,988\right.$, and $854 \mu \mathrm{g} \mathrm{g}^{-1}$, respectively), while Protector showed the lowest BX concentration, both at T1 (although not significant) and T2.
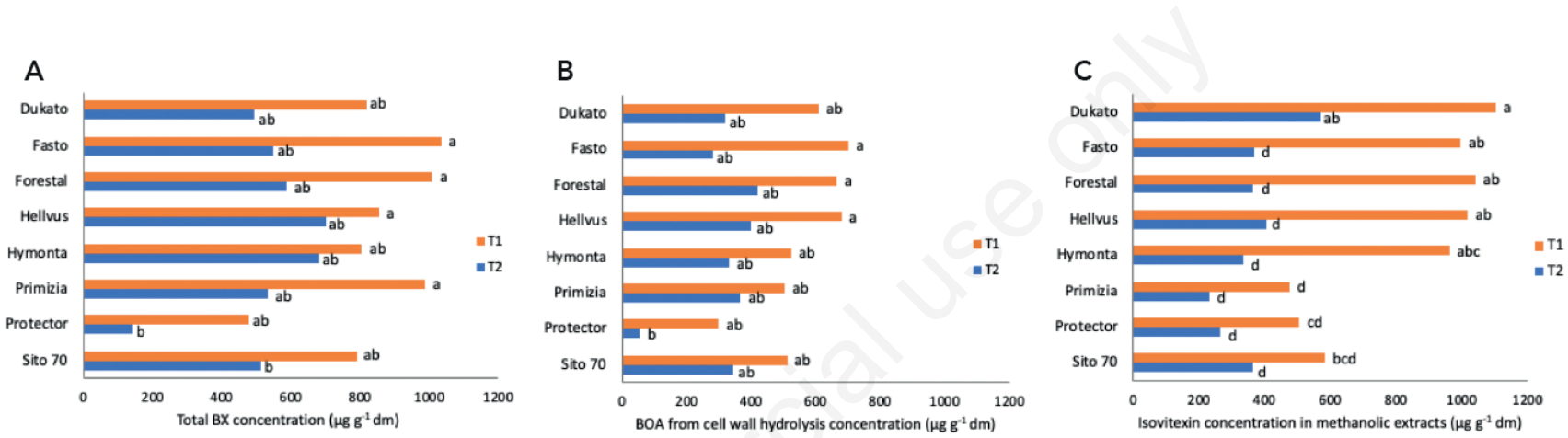

Figure 3. Concentration of allelochemicals in dry biomass at T1 and T2: A) total benzoxazinoids (BX) concentration; B) benzoxazolin$2(3 \mathrm{H})$-one $(\mathrm{BOA})$ concentration from cell wall hydrolysis; $\mathrm{C})$ isovitexin concentration in methanolic extracts. For each rye variety, means followed by different letters are significantly different according to the Tukey test $(P \leq 0.05)$.

Table 3. Rye plant height and rye biomass production at T1 and T2, and weed biomass in mulched and control plots 30 days after rye termination in the field trial.

\begin{tabular}{|c|c|c|c|c|c|}
\hline Variety & Termination & $\begin{array}{c}\text { Plant height } \\
(\mathrm{cm})\end{array}$ & $\begin{array}{l}\text { Fresh biomass } \\
\qquad\left(\mathrm{Mg} \mathrm{ha}^{-1}\right)\end{array}$ & $\begin{array}{c}\text { Dry biomass } \\
\left(\mathrm{Mg} \mathrm{ha}^{-1}\right)\end{array}$ & $\begin{array}{l}\text { Weed biomass } \\
\qquad\left(\mathrm{g} \mathrm{m}^{-2}\right)\end{array}$ \\
\hline Dukato & $\begin{array}{l}\mathrm{T} 1 \\
\mathrm{~T} 2\end{array}$ & $\begin{array}{c}71^{\mathrm{g}} \\
104^{\mathrm{ef}}\end{array}$ & $\begin{array}{c}7.8^{\mathrm{d}} \\
32.3^{\mathrm{abc}}\end{array}$ & $\begin{array}{l}2.4^{\mathrm{g}} \\
4.4^{\mathrm{efg}}\end{array}$ & $\begin{array}{l}11.8^{\mathrm{bc}} \\
13.7^{\mathrm{b}}\end{array}$ \\
\hline Fasto & $\begin{array}{l}\text { T1 } \\
\text { T2 }\end{array}$ & $\begin{array}{c}128^{\mathrm{e}} \\
154^{\mathrm{bcd}}\end{array}$ & $\begin{array}{l}27.7^{\mathrm{cd}} \\
38.6^{\text {ab }}\end{array}$ & $\begin{array}{c}4.2^{\mathrm{efg}} \\
6.5^{\mathrm{bcde}}\end{array}$ & $\begin{array}{c}9.2^{\mathrm{bc}} \\
12.1^{\mathrm{bc}}\end{array}$ \\
\hline Forestal & $\begin{array}{l}\text { T1 } \\
\text { T2 }\end{array}$ & $\begin{array}{c}97^{\mathrm{ef}} \\
168^{\mathrm{abc}}\end{array}$ & $\begin{array}{c}31.9^{\mathrm{abc}} \\
41.9^{\mathrm{a}}\end{array}$ & $\begin{array}{l}3.6^{\mathrm{fg}} \\
9.0^{\mathrm{a}}\end{array}$ & $\begin{array}{l}6.2^{\mathrm{bc}} \\
8.9^{\mathrm{bc}}\end{array}$ \\
\hline Hellvus & $\begin{array}{l}\text { T1 } \\
\text { T2 }\end{array}$ & $\begin{array}{c}102^{\mathrm{ef}} \\
155^{\mathrm{bcd}}\end{array}$ & $\begin{array}{l}30.2^{\mathrm{bc}} \\
38.4^{\mathrm{ab}}\end{array}$ & $\begin{array}{l}4.1^{\mathrm{efg}} \\
8.5^{\mathrm{ab}}\end{array}$ & $\begin{array}{l}7.8^{\mathrm{bc}} \\
9.4^{\mathrm{bc}}\end{array}$ \\
\hline Hymonta & $\begin{array}{l}\mathrm{T} 1 \\
\mathrm{~T} 2\end{array}$ & $\begin{array}{c}95^{\mathrm{f}} \\
157^{\mathrm{bcd}}\end{array}$ & $\begin{array}{l}29.6^{\mathrm{bc}} \\
38.2^{\mathrm{ab}}\end{array}$ & $\begin{array}{l}3.4^{\mathrm{fg}} \\
8.3^{\mathrm{ab}}\end{array}$ & $\begin{array}{l}7.0^{\mathrm{bc}} \\
7.7^{\mathrm{bc}}\end{array}$ \\
\hline Primizia & $\begin{array}{l}\mathrm{T} 1 \\
\mathrm{~T} 2\end{array}$ & $\begin{array}{l}157^{\mathrm{cd}} \\
174^{\mathrm{ab}}\end{array}$ & $\begin{array}{l}34.7^{\mathrm{abc}} \\
36.8^{\mathrm{abc}}\end{array}$ & $\begin{array}{l}5.6^{\text {cdef }} \\
7.5^{\text {abcd }}\end{array}$ & $\begin{array}{l}8.7^{\mathrm{bc}} \\
10.2^{\mathrm{bc}}\end{array}$ \\
\hline Protector & $\begin{array}{l}\mathrm{T} 1 \\
\mathrm{~T} 2\end{array}$ & $\begin{array}{l}136^{\mathrm{d}} \\
192^{\mathrm{a}}\end{array}$ & $\begin{array}{l}34.1^{\mathrm{abc}} \\
37.3^{\mathrm{abc}}\end{array}$ & $\begin{array}{c}5.5^{\text {cdef }} \\
9.0^{\mathrm{a}}\end{array}$ & $\begin{array}{c}10.2^{\mathrm{bc}} \\
2.5^{\mathrm{c}}\end{array}$ \\
\hline Sito 70 & $\begin{array}{l}\mathrm{T} 1 \\
\mathrm{~T} 2\end{array}$ & $\begin{array}{c}14^{3 \mathrm{~cd}} \\
151^{\mathrm{bcd}}\end{array}$ & $\begin{array}{l}34.7^{\mathrm{abc}} \\
37.8^{\mathrm{abc}}\end{array}$ & $\begin{array}{l}5.2^{\text {def }} \\
7.9^{\text {abc }}\end{array}$ & $\begin{array}{l}10.6^{\mathrm{bc}} \\
8.7^{\mathrm{bc}}\end{array}$ \\
\hline Control & $\begin{array}{l}\mathrm{T} 1 \\
\mathrm{~T} 2\end{array}$ & - & - & - & $\begin{array}{l}31.0^{\mathrm{a}} \\
35.6^{\mathrm{a}}\end{array}$ \\
\hline Average & & 137 & 33.9 & 5.95 & 11.7 \\
\hline
\end{tabular}

a-g Within the columns, means followed by different letters are significantly different according to the Tukey test $(\mathrm{P} \leq 0.05)$ 
The total BX concentration includes BOA fixed into the cell wall (BOA from cell wall hydrolysis), representing a large portion of BOA (Figure 3B). The BOA derived from cell wall hydrolysis decreased by $44 \%$ from $\mathrm{T} 1\left(561 \mu \mathrm{g} \mathrm{g}^{-1}\right)$ to $\mathrm{T} 2\left(314 \mu \mathrm{g} \mathrm{g}^{-1}\right)$.

Considering the flavonoid fraction, the isovitexin concentration detected in the methanolic extract followed a similar pattern to that of the total $\mathrm{BX}$ concentration and the cell wall fixed-BOA (Figure $3 \mathrm{C}$ ): it decreased by about $57 \%$ from T1 to T2. Dukato had the greatest isovitexin concentration at $\mathrm{T} 1\left(1103 \mu \mathrm{g} \mathrm{g}^{-1}\right)$, while Protector and Primizia had the lowest (506 and $476 \mu \mathrm{g} \mathrm{g}^{-1}$, respectively). The isovitexin concentration in dry biomass of Dukato was considerably higher $(+71 \%)$ than the average value of the other cultivars, also at $\mathrm{T} 2$.

\section{Field experiment: weeding effect of rye mulch}

A different development of weeds was observed according to rye variety within 30 days after termination (Table 3 ).

The dry biomass of weeds was not affected by rye variety, although all of them showed lower values than that detected under the control (Table 3). On average, the dry biomass of weeds was 9 $\mathrm{g} \mathrm{m}^{-2}$, while the correspondent value for the control plots was 33.3 $\mathrm{g} \mathrm{m}^{-2}$ (about 4 times higher). The weed dry biomass was not significantly different for the rye terminated at T2 than at T1. Also, the interaction $\mathrm{V} \times \mathrm{T}$ was not significant (Table 2). The weed community was mainly represented by: Polygonum aviculare L. (common knotgrass), Amaranthus retroflexus L. (redroot pigweed), Fallopia convolvulus L. Á Löwe (black-bindweed), Anagallis arvensis L. (scarlet pimpernel), Lamium purpureum L. (red-dead nettle), and Cirsium arvense L. (creeping thistle).

Results of the correlation analysis (Table 4) showed that the weed biomass detected after T1 was significantly affected by the allelochemical content in rye biomass: a negative correlation was indeed observed between weed biomass and allelochemical content in rye tissues.

On the contrary, the rye biomass (mulch) left on the soil sur- face had no significant effect after T1.

Unlike what was observed after T1, the weed biomass detected after T2 rye termination was negatively affected by the rye biomass production, while the allelochemical content did not influence it significantly.

\section{Pot experiment: weeding effect of rye mulch on sum- mer weeds}

In the pot trial (Table 5), the number of seedlings of $A$. theophrast $i$ that emerged in the mulched pots was not significantly different from that detected in the control ones. Instead, in the mulched pots, the emergence of $A$. theophrasti seedlings tended to be higher $(+35 \%$, on average) than in the control pots, although without statistical significance. Different results were observed for the other three summer weeds.

For $C$. album, the number of weed seedlings that emerged in the mulched pots of all the rye varieties was significantly reduced compared with the control. The highest decrease of weed germination was observed for Protector, Forestal, Hymonta, and Hellvus, which exhibited a reduction of C. album development from 92 to $84 \%$ compared to the control. Fasto showed the lowest inhibitory effect $(-50 \%$ than the control), while the weed development in the pots mulched with Primizia, Sito 70, and Dukato was intermediate among the previous varieties.

The average development of mulched pots with $A$. retroflexus was $56 \%$ lower than that observed in the control, and the most significant weed suppression occurred for Forestal (-82\%). In comparison, Dukato exerted the lowest inhibitory effect $(-22 \%)$, proving to be no different from the control. Primizia, Protector, and Hymonta resulted were intermediate between the two, although all exhibited a percentage of weed development reduction over $60 \%$.

The higher average weed suppression was observed for $P$. oleracea $(-84 \%)$ : the percentage of seeds germinated ranged from 11 to $28 \%$ of the control. Definitely, P. oleracea was easily controlled by all rye cultivars.

Table 4. Pearson's correlation coefficients ( $r$ ) between mulch amount, allelochemical content in mulch and weed biomass. Weed biomass was assessed twice: 30 days after T1 and 30 days after T2. P-values are also reported.

\begin{tabular}{|c|c|c|c|c|c|c|c|c|}
\hline \multirow[t]{2}{*}{ Variable } & \multicolumn{2}{|c|}{ Rye biomass production } & \multicolumn{2}{|c|}{ BX content } & \multicolumn{2}{|c|}{ BOA content in $\mathrm{cw}$} & \multicolumn{2}{|c|}{ Isovitexin content } \\
\hline & r & P-value & $\mathbf{r}$ & P-value & $\mathbf{r}$ & P-value & $\mathbf{r}$ & P-value \\
\hline Weed biomass after T1 & -0.7753 & 0.7267 & -0.4782 & 0.0181 & -0.6228 & 0.0012 & -0.6507 & 0.0006 \\
\hline Weed biomass after T2 & -0.7729 & $<0.0001$ & 0.0823 & 0.7024 & -0.131 & 0.5417 & -0.2715 & 0.1994 \\
\hline
\end{tabular}

BOA, benzoxazolin-2 (3H)-one; BX, benzoxazinoids; cw, cell wall.

Table 5. Percentage of weed seedlings emerged up to 30 days after sowing of four weeds, compared to the control without mulch.

\begin{tabular}{|c|c|c|c|c|c|}
\hline Variety & Mulch (g d.m. pot ${ }^{-1}$ ) & A. theophrasti (\%) & C. album (\%) & A. retroflexus (\%) & P. oleracea (\%) \\
\hline Dukato & 12.3 & 70 & $23^{b c}$ & $43^{\mathrm{ab}}$ & $6^{\text {b }}$ \\
\hline Fasto & 13.9 & 65 & $32^{\mathrm{b}}$ & $24^{\mathrm{abc}}$ & $7^{\mathrm{b}}$ \\
\hline Forestal & 10.3 & 63 & $8^{c}$ & $10^{c}$ & $2^{b}$ \\
\hline Hellvus & 12.4 & 69 & $8^{c}$ & $21^{\mathrm{abc}}$ & $8^{b}$ \\
\hline Hymonta & 10.5 & 61 & $10^{c}$ & $38^{b c}$ & $4^{b}$ \\
\hline Primizia & 14.8 & 69 & $18^{b c}$ & $18^{\mathrm{bc}}$ & $11^{\mathrm{b}}$ \\
\hline Protector & 14.8 & 63 & $5^{c}$ & $18^{\mathrm{bc}}$ & $5^{b}$ \\
\hline Sito 70 & 13.7 & 68 & $18^{b c}$ & $30^{\mathrm{abc}}$ & $6^{\mathrm{b}}$ \\
\hline Control & - & 49 & $63^{\mathrm{a}}$ & $55^{\mathrm{a}}$ & $38^{\mathrm{a}}$ \\
\hline P-value & & 0.7304 & $<0.0001$ & 0.0022 & $<0.0001$ \\
\hline
\end{tabular}

a-c Within the columns, means followed by different letters are significantly different $(\mathrm{P} \leq 0.05)$. 


\section{Discussion}

\section{Rye biomass production and inhibitory effect on weed development in the field}

Values of rye biomass production observed in the present study are consistent with those reported by previous research carried out by Nair and Ngouajio (2012), who found that rye may produce up to $8 \mathrm{Mg} \mathrm{ha}^{-1}$ of dry biomass for late-April termination date under a similar climate. Although the field experiment results refer only to a single location and one season, we can affirm that Protector was the most productive variety in our soil-climate conditions, closely followed by Primizia, Sito 70, Hellvus Forestal, and Hymonta. The significant increase in biomass production from the heading stage to the beginning of the flowering stage was previously documented by Clark et al. (1994). They observed that rye biomass production increases significantly $(+75 \%)$ if the spring termination is delayed (from the beginning of April to the beginning of May). In addition, Mischler et al. (2010) reported that the height of rye plants increased from 83 to $100 \%$, while the biomass production doubled when the rye kill was postponed for 10 days.

The mulch left onto the soil surface was reported to be directly related to the inhibition of weed development due to both physical and allelochemical effects on germination of weed seeds (Smith et al., 2011). Results of the correlation analysis confirmed the inhibitory effect on weed biomass due to rye mulching, showing that this effect was exerted by different factors depending on the timing of termination. Our study observed a significant negative correlation between allelochemical content (above all isovitexin content) and weed biomass after $\mathrm{T} 1$ termination, while the rye biomass production seemed to play no substantial effect on weed development at this termination timing. Conversely, the weed biomass was negatively correlated with the amount of rye mulch after T2 termination, when the rye biomass highly increased compared with $\mathrm{T} 1$ termination (on average $+77 \%$ ). It follows that the content of allelochemicals in rye biomass, and its consequent release during the degradation of plant tissues (Schulz et al., 2013), could be considered one of the main drivers for the inhibition of weed development if rye is terminated at an early stage of growth. On the contrary, the amount of biomass surpasses the allelochemical content if rye is terminated later. Indeed, the rye mulch may exert a physical suppression of weed seedlings, mainly due to a reduction of soil temperature and light penetration, which both have been recognized to limit weed germination (Teasdale and Mohler, 2000; Kruidhof et al., 2009).

Contrary to our hypothesis, the early rye termination did not enhance the control of weeds compared to the late one, as the suppressing effect on weeds due to the allelochemicals after T1 was replaced by that exerted by the rye biomass production after $\mathrm{T} 2$.

\section{Field experiment: allelochemical concentration as affected by rye variety and termination timing}

The BX concentration detected in rye cultivars was higher than that found in previous studies. For instance, Tabaglio et al. (2013) reported that $\mathrm{BX}$ concentration ranged between 177 and $545 \mu \mathrm{g} \mathrm{g}^{-1}$ for 7 greenhouse-grown rye cultivars considered in their research, while Rice et al. (2012) found considerably lower values of BX

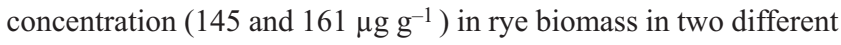
sites. The higher BX concentration detected in our study was probably due to the $\mathrm{N}$ fertilizer applied to the cover crop: Gavazzi et al. (2010) observed that the distribution of $50 \mathrm{~kg} \mathrm{~N} \mathrm{ha}^{-1}$ led to an increase of benzoxazinoid concentration by $41 \%$ in comparison with an unfertilized control. Schulz et al. (2013) confirmed these results, reporting that severe nitrogen shortage may reduce the $\mathrm{BX}$ content in the rye.

In addition, as previously reported by Reberg-Horton et al. (2005), the allelochemical concentration in rye tissues decreased with the plant aging for all the cultivars. Such an observation confirms the existence of a temporal pattern of allelochemical production (Gianoli et al., 2000).

Considering the total amount of BX, we found that a large part of BOA was bound to the cell wall. However, it is presently unclear whether the fixation occurs during the drying process of the plant material or whether the compound is already bound to cell wall carbohydrates after it is released and abundant in the apoplastic space of the living rye plant. In the latter case, the deposition may strengthen pathogen resistance and influence cell wall degradability (Mnich et al., 2020). Whichever, crop residues, including mulches, are known sources for bioactive secondary compounds, such as biopesticides and allelochemicals as well (Santana-Méridas et al., 2012). These compounds can be released, for instance, by microbial cellulases or other bacterial or fungal enzymes when the decay of the mulch starts. Therefore, while the fixation of BOA into the cell wall may reduce the allelopathic potential of rye mulch obtained immediately after termination, the subsequent degradation of mulch due to microbial activities may promote the liberation of the cell wall-bound BOA and probably additional allelochemicals (not tested in this study), thus eventually affecting the long-term allelopathic effect positively.

\section{Inhibition of summer weed in the pot experiment}

The absence of any inhibition performed by rye mulch on $A$. theophrasti emergence is consistent with results of our previous studies (Tabaglio et al., 2008; Schulz et al., 2013), reporting that the presence of a rye mulch did not reduce the $A$. theophrasti growth, but instead tends to encourage the germination of the weed seeds. This is probably related to the higher humidity and temperature of the soil below the mulch than in the uncovered soil (Weil and Kremen, 2007). In addition, it was observed that the activity of rhizosphere bacteria and root colonizing microorganisms could help A. theophrasti detoxify benzoxazinoids (Haghi Kia et al., 2014; Schulz et al., 2017).

For the other common summer weeds, the reduction of seedling emergence was very high compared to the control, corroborating findings from previous studies. For example, Putnam and DeFrank (1983) reported an emergence reduction of $A$. retroflexus by $95 \%$, and $P$. oleracea by $100 \%$, within 30 to 60 days after the placement of rye residues on the soil; Tabaglio et al. (2008) observed that rye mulch significantly reduced seedling emergence of $A$. retroflexus (up to $52 \%$ ) and purslane (up to $74 \%$ ), while failed to inhibit the development of C. album.

Further reports confirmed these outcomes and showed that smaller-seeded species are more sensitive to allelochemicals (Tabaglio et al., 2008) and that seed mass is crucial for the selective suppression of weeds with crop residues (Kruidhof et al., 2009).

We assessed the inhibitory effect of rye mulch on summer weeds only using rye biomass cut at $\mathrm{T} 1$; future research may evaluate the suppressing effect on weed of rye biomass cut at a late stage of growth.

\section{Implications for sustainable weed management}

A better understanding of the allelopathic effect of rye mulch under field conditions and the actual role due to some agricultural 
practices (e.g., choice of the cultivar, fertilization, timing, and system of cover crop termination) on weed suppression would provide the means to profitably include rye cover as a complementary strategy in weed management, especially within organic farming systems.

The restraining effect on weed growth should be considered in the integrated weed control strategy because it can allow the reduction in the rate of herbicide applied to cash crops following rye cover crop, as also requested by the new EU strategy named 'Farm to Fork' (European Commission, 2020).

It was observed that rye mulching can represent a sustainable weed management practice, allowing a reduction of the herbicides used in agro-ecosystems by eliminating the need for pre-emergence applications (Reddy, 2001). Wallace and Bellinder (1990) observed that the presence of a rye mulch suppressed weed growth and allowed the use of reduced rates of linuron, metribuzin, and oryzalin. However, Reddy (2001) found that the cover crop mulching should be accompanied by the application of post-emergence herbicide to complement early-season weed suppression.

In addition, rye cultivar-dependent exudation pathways are unknown, nor is the degree of long-distance transport of benzoxazinoids and the allelopathic potential of BX fixed to the cell wall. Some specific considerations for further research needs are: i) to identify detoxification potentials of crop cultivars in order to realize breeding strategies; ii) to realize systematic analysis about BX content in rye cultivars as a function of environmental factors; and iii) to study BX accumulation patterns intensively in rye plants during growth in order to choose the best timing for the cover crop termination. These questions should be addressed if rye allelopathy is to be used more commonly in the future.

\section{Conclusions}

Results of the present study confirm that adopting rye as a cover crop may be considered a suitable practice to reduce weed pressure at the field level. At the same time, the role of rye variety in the production rate of allelochemicals and the importance of the interaction between variety and termination time are confirmed. Among all the varieties tested, Protector and Forestal showed a higher potential to inhibit weed development: Forestal maximized the allelochemical production, whereas Protector showed the highest biomass production. Cell wall-bound BOA is assumed to contribute to long-term allelopathy of rye mulch.

Delaying the cover crop termination leads to a significant increase in biomass production, but the concentration of allelochemicals in the biomass, especially for isovitexin, decreased.

The reduction of weed biomass 30 days after the rye termination was strongly correlated with the allelochemical content in the case of the early termination, while with the rye biomass production in the case of delayed termination.

In addition, we found that rye mulches could not suppress the growth of $A$. theophrasti seedlings, while the growth of seedlings of $A$. retroflexus, $P$. oleracea, and $C$. album was significantly affected. This fact endorses that $A$. theophrasti could activate mechanisms of detoxification promoted by the associated microbiotas.

Yet, we should remember that, this study was conducted in one year. Although weather conditions during this period could be considered typical, further studies are needed to verify that results remain consistent in wetter and/or drier years and in the middleand long-term.

\section{References}

Anders N, Humann H, Langhans B, Spieß AC, 2015. Simultaneous determination of acid-soluble biomass-derived compounds using high performance anion exchange chromatography coupled with pulsed amperometric detection. Anal. Methods 7:7866-73.

Anders N, Schelden M, Roth S, Spiess AC, 2017. Automated chromatographic laccase-mediator-system activity assay. Anal. Bioanal. Chem. 409:4801-9.

Barnes JP, Putnam AR, 1983. Rye residues contribute weed suppression in no-tillage cropping systems. J. Chem. Ecol. 9:1045-57.

Beckie HJ, 2020. Herbicide resistance in plants. Plants 9:7-10.

de Bertoldi C, De Leo M, Braca A, Ercoli L, 2009. Bioassay-guided isolation of allelochemicals from Avena sativa L.: allelopathic potential of flavone C-glycosides. Chemoecology 19:169-76.

Clark AJ, Decker AM, Meisinger JJ, Clark AJ, Decker AM, 1994. Seeding rate and kill date effects on hairy vetch-cereal rye cover crop mixtures for corn production. Agronomy J. 86:1065-70.

European Commission, 2020. European Commission Communication from the Commission to the European Parliament, the Council, the European Economic and Social Committee and the Committee of the Regions. A Farm to Fork Strategy for a fair, Healthy and Environmentally-Friendly Food System, Brussels, 20.5.2020 COM(2020) 381 Final (2020). Available from: https://eur-lex.europa.eu/legal-content/EN/ALL/?uri=COM:2020:0381:FIN Accessed: 15 December 2020.

Felsot AS, Unsworth JB, Linders JBHJ, Roberts G, Rautman D, Harris C, Carazo E, 2011. Agrochemical spray drift; assessment and mitigation-a review. J. Environ. Sci. Heal. Part B Pestic. Food Contam. Agric. Wastes 46:1-23.

Fiorini A, Maris SC, Abalos D, Amaducci S, Tabaglio V, 2020. Combining no-till with rye (Secale cereale L.) cover crop mitigates nitrous oxide emissions without decreasing yield. Soil Tillage Res. 196:104442.

Gavazzi C, Schulz M, Marocco A, Tabaglio V, 2010. Sustainable weed control by allelochemicals from rye cover crops: From the greenhouse to field evidence. Allelopath. J. 25:259-73.

Gianoli E, Rios JM, Niemeyer HM, 2000. Allocation of a hydroxamic acid and biomass during vegetative development in rye. Acta Agric. Scand. Sect. B Soil Plant Sci. 50:35-9.

Haghi Kia S, Schulz M, Ayah E, Schouten A, Müllenborn C, Paetz C, Schneider B, Hofmann D, Disko U, Tabaglio V, Marocco A, 2014. Abutilon theophrasti's defense against the allelochemical benzoxazolin-2(3H)-One: support by actinomucor elegans. J. Chem. Ecol. 40:1286-98.

Hiltbrunner J, Jeanneret P, Liedgens M, Stamp P, Streit B, 2007. Response of weed communities to legume living mulches in winter wheat. J. Agron. Crop Sci. 193:93-102.

Kruidhof HM, Bastiaans L, Kropff MJ, 2009. Cover crop residue management for optimizing weed control. Plant Soil 318:169-84.

Kumar V, Mahajan G, Dahiya S, Chauhan BS, 2020. Challenges and opportunities for weed management in no-till farming systems. In: Y.P. Dang, R.C. Dalal, N.W. Menzies (Eds.), No-till farming systems for sustainable agriculture: challenges and opportunities. Springer International Publishing, Berlin, Germany, pp 107-25.

Liebman M, Davis AS, 2015. Managing weeds in organic farming 
systems: an ecological approach. In: C. Francis (Ed.), Organic farming: the ecological system, vol. 54. Wiley Publishing, Hoboken, NJ, USA, pp. 173-95.

Macías FA, Mejías FJR, Molinillo JMG, 2019. Recent advances in allelopathy for weed control: from knowledge to applications. Pest Manag. Sci. 75:2413-36.

Mirsky SB, Ryan MR, Teasdale JR, Curran WS, Reberg-Horton CS, Spargo JT, Wells MS, Keene CL, Moyer JW, 2013. Overcoming weed management challenges in cover cropbased organic rotational no-till soybean production in the Eastern United States. Weed Technol. 27:193-203.

Mischler RA, Curran WS, Duiker SW, Hyde JA, 2010. Use of a rolled-rye cover crop for weed suppression in no-till soybeans. Weed Technol. 24:253-61.

Mnich E, Bjarnholt N, Eudes A, Harholt J, Holland C, Jørgensen B, Larsen FH, Liu M, Manat R, Meyer AS, Mikkelsen JD, Motawia MS, Muschiol J, Møller BL, Møller SR, Perzon A, Petersen BL, Ravn JL, Ulvskov P, 2020. Phenolic cross-links: building and de-constructing the plant cell wall. Nat. Prod. Rep. 37:919-61.

Nair A, Ngouajio M, 2012. Soil microbial biomass, functional microbial diversity, and nematode community structure as affected by cover crops and compost in an organic vegetable production system. Appl. Soil Ecol. 58:45-55.

Putnam AR, DeFrank J, 1983. Use of phytotoxic plant residues for selective weed control. Crop Prot. 2:173-81.

Reberg-Horton SC, Burton JD, Danehower DA, Ma G, Monks DW, Murphy JP, Ranells NN, Williamson JD, Creamer NG, 2005. Changes over time in the allelochemical content of ten cultivars of rye (Secale cereale L.). J. Chem. Ecol. 31:179-93.

REDDY KN, 2001. Effects of Cereal and Legume Cover Crop Residues on Weeds, Yield, and Net Return in Soybean (Glycine max) 1. Weed Technol. 15:660-8.

Rice CP, Cai G, Teasdale JR, 2012. Concentrations and allelopathic effects of benzoxazinoid compounds in soil treated with rye (secale cereale) cover crop. J. Agric. Food Chem. 60:4471-9.

Rice CP, Yong BP, Adam F, Abdul-Baki AA, Teasdale JR, 2005. Hydroxamic acid content and toxicity of rye at selected growth stages. J. Chem. Ecol. 31:1887-905.

Santana-Méridas O, González-Coloma A, Sánchez-Vioque R, 2012. Agricultural residues as a source of bioactive natural products. Phytochem. Rev. 11:447-66.

Scavo A, Abbate C, Mauromicale G, 2019. Plant allelochemicals: agronomic, nutritional and ecological relevance in the soil system. Plant Soil 442:23-48.

Schulz M, Filary B, Kühn S, Colby T, Harzen A, Schmidt J, Sicker D, Hennig L, Hofmann D, Disko U, Anders N, 2016. Benzoxazolinone detoxification by N-Glucosylation: The multi-compartment-network of Zea mays L. Plant Signal. Behav. 11:e1119962.

Schulz M, Marocco A, Tabaglio V, Macias FA, Molinillo JMG, 2013. Benzoxazinoids in rye allelopathy - from discovery to application in sustainable weed control and organic farming. J. Chem. Ecol. 39:154-74.

Schulz M, Sicker D, Schackow O, Hennig L, Yurkov A, Siebers M, Hofmann D, Disko U, Ganimede C, Mondani L, Tabaglio V, Marocco A, 2017. Interspecies-cooperations of abutilon theophrasti with root colonizing microorganisms disarm BOA$\mathrm{OH}$ allelochemicals. Plant Signal. Behav. 12.

Sluiter A, Hames B, Ruiz CS, Slui JD. Templeton and DC, 2008. Determination of structural carbohydrates and lignin in biomass: laboratory analytical procedure (LAP); issue date: April 2008; revision date: July 2011 (version 07-08-2011) 42618.pdf. Tech. Rep. NREL/ TP -510 -42618:1-15. Available from: http:/www.nrel.gov/biomass/pdfs/42618.pdf

Smith AN, Reberg-Horton SC, Place GT, Meijer AD, Arellano C, Mueller JP, 2011. Rolled Rye Mulch for Weed Suppression in Organic No-Tillage Soybeans. Weed Sci. 59:224-31.

Tabaglio V, Gavazzi C, Schulz M, Marocco A, 2008. Alternative weed control using the allelopathic effect of natural benzoxazinoids from rye mulch. Agron. Sustain. Dev. 28:397-401.

Tabaglio V, Marocco A, Schulz M, 2013. Allelopathic cover crop of rye for integrated weed control in sustainable agro-ecosystems. Ital. J. Agron. 8:35-40.

Teasdale JR, Mohler CL, 2000. The quantitative relationship between weed emergence and the physical properties of mulches. Weed Sci. 48:385-92.

Wallace RW, Bellinder RR, 1990. Low-rate applications of herbicides in conventional and reduced tillage potatoes (Solanum tuberosum). Weed. Technol. 4:509-13.

Wayman S, Cogger C, Benedict C, Collins D, Burke I, Bary A, 2015. Cover crop effects on light, nitrogen, and weeds in organic reduced tillage. Agroecol. Sustain. Food Syst. 39:647-65.

Weil R, Kremen A, 2007. Thinking across and beyond disciplines to make cover crops pay. J. Sci. Food Agric. 84: 551-7. 